\title{
Genetic testing in familial isolated hyperparathyroidism: unexpected results and their implications
}

\author{
J Warner, M Epstein, A Sweet, D Singh, J Burgess, S Stranks, P Hill, D Perry-Keene, D Learoyd, \\ B Robinson, P Birdsey, E Mackenzie, B T Teh, J B Prins, J Cardinal
}

See end of article for authors' affiliations

Correspondence to:

Prof J B Prins, Department of Diabetes and Endocrinology, Princess Alexandra Hospital Ipswich Rd,

Woolloongabba, 4102

Qld, Australia; iprins@

soms.uq.edu.au

Received

21 November 2003

Accepted

21 November 2003
Familial hyperparathyroidism is not uncommon in clinical endocrine practice. It encompasses a spectrum of disorders including multiple endocrine neoplasia types 1 (MEN1) and 2A, hyperparathyroidism-jaw tumour syndrome (HPT-JT), familial hypocalciuric hypercalcaemia (FHH), and familial isolated hyperparathyroidism (FIHP). Distinguishing among the five syndromes is often difficult but has profound implications for the management of patient and family. The availability of specific genetic testing for four of the syndromes has improved diagnostic accuracy and simplified family monitoring in many cases but its current cost and limited accessibility require rationalisation of its use. No gene has yet been associated exclusively with FIHP. FIHP phenotypes have been associated with mutant MENI and calcium-sensing receptor (CASR) genotypes and, very recently, with mutation in the newly identified HRPT2 gene. The relative proportions of these are not yet clear. We report results of MEN1, CASR, and HRPT2 genotyping of 22 unrelated subjects with FIHP phenotypes. We found 5 (23\%) with MEN1 mutations, four (18\%) with CASR mutations, and none with an HRPT2 mutation. All those with mutations had multiglandular hyperparathyroidism. Of the subjects with CASR mutations, none were of the typical $\mathrm{FHH}$ phenotype. These findings strongly favour a recommendation for MEN1 and CASR genotyping of patients with multiglandular FIHP, irrespective of urinary calcium excretion. However, it appears that HRPT2 genotyping should be reserved for cases in which other features of the HPT-JT phenotype have occurred in the kindred. Also apparent is the need for further investigation to identify additional genes associated with FIHP.

\section{INTRODUCTION}

The term familial hyperparathyroidism encompasses a spectrum of disorders in which primary hyperparathyroidism (persistent hypercalcaemia in the presence of inappropriately normal or elevated parathyroid hormone) $)^{1}$ is inherited, usually in autosomal dominant fashion. It occurs either alone or as part of a syndrome including tumours of other tissues. The spectrum includes multiple endocrine neoplasia types I (MEN1) and 2A (MEN2A), hyperparathyroidism-jaw tumour syndrome (HPT-JT), familial hypocalciuric hypercalcaemia (FHH) (also known as familial benign hypercalcaemia), and familial isolated hyperparathyroidism (FIHP). ${ }^{23}$

As the management and prognosis of these conditions vary considerably, the ability to accurately categorise a patient's familial hyperparathyroidism is crucial. In only a proportion, however, will a definitive diagnosis be apparent simply from the clinical findings and family history. The discovery of genes associated with MEN1, ${ }^{4}$ MEN2A, ${ }^{5} \mathrm{HPT}_{-} \mathrm{JT}^{6}$ and $\mathrm{FHH}^{7}$ has allowed accurate diagnosis in more cases as well as screening of family members of patients with mutations identified in these genes. Nevertheless, approximately 13\% of patients with MEN1, ${ }^{8} 2 \%$ with MEN2A, ${ }^{9} 40 \%$ with HPT-JT and $40 \%$ with $\mathrm{FHH}^{10}{ }^{11}$ phenotypes do not have sequence variations demonstrable in the protein coding regions of known genes by standard PCR-based mutation detection methods.

Gene discovery has also revealed that mutant MEN1, ${ }^{12} 13$ $C A S R^{14} 15$, or $H_{R P T 2}{ }^{6}$ genotypes may express only the FIHP phenotype. The relative proportions of these are still being elucidated, however, the cost and limited availability of genetic diagnostic tests currently preclude the option of testing all genes known to be associated with inherited hyperparathyroidism in all patients with familial hyperparathyroidism in clinical practice.
FIHP is essentially a diagnosis of exclusion. The clinical picture is of familial primary hyperparathyroidism in the absence of sufficient clinical, radiological or biochemical evidence for diagnoses of MEN 1, MEN2A, HPT-JT, or FHH to be made. Its incidence has been estimated to be about $1 \%$ of all cases of primary hyperparathyroidism. ${ }^{14}$ Histologically, parathyroid chief cell hyperplasia, ${ }^{16} \operatorname{single}^{17}$ and multiple gland adenomata ${ }^{17}{ }^{18}$ as well as parathyroid carcinomata ${ }^{17} 18$ have been implicated.

FHH, usually caused by heterozygous inactivating mutations of CASR on chromosome $3 \mathrm{q},{ }^{3}{ }^{19}$ is the most difficult of the familial hyperparathyroidism syndromes to distinguish clinically from FIHP. The prevalence of typical FHH in the west of Scotland has been estimated to be 1 in $78000^{20}$ which makes it about as common as FIHP. ${ }^{14}$ Characteristic features of mild to moderate hypercalcaemia ${ }^{21}$ non-suppressed parathyroid hormone $(\mathrm{PTH})$, relative hypocalciuria while hypercalcaemic (calcium/creatinine clearance ratio $<0.01$ or $24 \mathrm{~h}$ urine calcium $<6.25 \mathrm{mmol}$ ), ${ }^{121}$ almost $100 \%$ penetrance of the gene for hypercalcaemia from birth, absence of complications, persistence of hypercalcaemia following subtotal parathyroidectomy, ${ }^{21}$ and normal parathyroid size, weight, and histology at surgery ${ }^{22}$ facilitate the diagnosis when present. However, atypical presentations with severe hypercalcaemia, ${ }^{23}$ hypercalciuria (with or without nephrolithiasis or nephrocalcinosis), ${ }^{15}$ kindreds with affected members displaying either hypercalciuria or hypocalciuria, ${ }^{14}{ }^{24}$ normocalcaemia resulting from surgery ${ }^{1521}$ and pancreatitis ${ }^{25}$ have

Abbreviations: CASR, calcium-sensing receptor; $\mathrm{FHH}$, familial hypocalciuric hypercalcaemia; FIHP, familial isolated hyperparathyroidism; HPT-JT, hyperparathyroidism-jaw tumour syndrome; MEN1, multiple endocrine neoplasia type 1; MTC, medullary thyroid carcinoma; PTH, parathyroid hormone 
all been described. A further limitation in the discriminating between FHH and primary hyperparathyroidism of other aetiologies is that about $1 / 3$ of subjects with mild primary hyperparathyroidism have been shown to have relative hypocalciuria when hypercalcaemic. ${ }^{26}$

The general recommendation is that if a diagnosis of FHH is suspected, the kindred should be investigated. This may resolve diagnostic uncertainty, however if there are atypical features in the kindred, it may not. Furthermore, access to a sufficiently large kindred may not be possible if only a small one exists or for privacy or other reasons. In addition, if the index case presents with atypical features, the diagnosis may reasonably be regarded unlikely.

At present, no gene has been associated exclusively with the FIHP phenotype. We have taken advantage of the recent discovery of HRPT2 to combine mutation analysis of MEN1, CASR, and HRPT2 in 22 apparently unrelated patients with clinical diagnoses of FIHP. We report the prevalence of sequence variations in the group, discuss their implications for patient management, and confirm the need for further investigation to clarify the genetic basis of FIHP.

\section{SUBJECTS AND METHODS Subjects}

Subjects were referred to this centre by clinicians in eastern Australia for genetic testing for inherited hyperparathyroidism as part of their clinical management. Informed consent was obtained from each subject by the referring clinician.

For a diagnosis of FIHP to be made, patients were required to have hypercalcaemia with a non-suppressed parathyroid hormone (PTH), ${ }^{1}$ a history of the same in one or more firstdegree relative(s), and histopathological evidence from surgery of parathyroid adenoma, carcinoma, or hyperplasia in the patient or relative. Prior to referral, MEN1, MEN2A, FHH and HPT-JT phenotypes had been excluded in known affected family members by clinical, biochemical, and radiological investigation. Investigations were carried out at the discretion of the consulting endocrinologist, in several cases over many years and two or three generations. They included, as a minimum, urinary calcium ( $24 \mathrm{~h}$ or fasting early morning spot urine collections) excretion, serum/ plasma calcitonin, prolactin, gonadotrophins, and fasting glucose and gastrin estimation. Additional investigations included pancreatic polypeptide, fasting insulin, insulin-like growth factor 1 , and thyroid function tests. Most had cerebral imaging by CT, MRI, or pituitary fossa x ray. All subjects with MENI sequence variations and all, but one, of their affected family members had had cerebral CT or MRI.

Affected family members as listed in tables 1 and 2 have had MEN1, MEN2A, FHH, and HPT-JT phenotypes excluded, with the following exceptions. In family $\mathrm{G}$ the 51 and 46 year old, in L the 35 year old and in $\mathrm{T}$ the 36 and 32 year old members were found to be hypercalcaemic after genetic testing was complete and are undergoing investigation.

In family $L$ the proband was normocalcaemic but had urolithiasis, hypercalciuria, persistently elevated PTH, no other cause found for elevated PTH, a family history of hyperparathyroidism, and was shown to have multigland hyperplasia (total gland weight: $390 \mathrm{mg}$ ) at surgery. He was included in this cohort.

In family I, the subject presented with hypercalcaemia and pancreatitis. His fasting (early morning spot) urine calcium/ creatinine ratio $(\mathrm{Ca} / \mathrm{Cr})$ was in the mid-normal range and he was found to have an 11 year old affected offspring, also with fasting urine $\mathrm{Ca} / \mathrm{Cr}$ in the upper normal range. This kindred was also included because of the presentation with pancreatitis, overwhelmingly more common in primary hyperparathyroidism than FHH, although the diagnosis of $\mathrm{FHH}$ was possible, considering the age of the affected offspring and persistence of hypercalcaemia after subtotal parathyroidectomy in the index case.

\section{Methods}

Biochemical testing of blood and urine and histopathological examination of surgical specimens were performed at nationally accredited laboratories within Australia. Plasma intact PTH levels were determined by immunoradiometric or immunochemiluminometric assay. Other biochemical tests were completed using standard automated techniques.

Germline mutation testing was performed in the Department of Diabetes and Endocrinology at Princess Alexandra Hospital. DNA for analysis was extracted from peripheral blood leukocytes using a published method. ${ }^{27}$ The protein coding regions with splice junctions of MENI, CASR, and HRPT2, and the putative promoter region of $M E N 1^{28}$ were amplified using gene specific primers (available on request) designed from intronic DNA sequence adjacent to intronexon boundaries or exonic DNA, when internal primers were required for larger exons. PCR reactions for individual exons were carried out in $50 \mu \mathrm{l}$ reaction volumes containing 2050 ng DNA, 10 pmol each primer, $5 \mu$ l GeneAmp 10X PCR Buffer II (Applied Biosystems), $3 \mu \mathrm{l} 25 \mathrm{mM} \mathrm{mgCl}_{2}$ Solution (Applied Biosystems), $500 \mathrm{mU}$ AmpliTaq Gold DNA polymerase (Applied Biosystems) and $250 \mathrm{nM}$ dNTPs. Thermal cycling was carried out in a FTS-960 Thermal Sequencer (Corbett Research). Cycling conditions consisted of an initial 10 min denaturation step at $94^{\circ} \mathrm{C}$ followed by 30 cycles of $94^{\circ} \mathrm{C}$ for $60 \mathrm{~s}$, annealing for $60 \mathrm{~s}$ and $72^{\circ} \mathrm{C}$ for $90 \mathrm{~s}$ with a final extension step at $72^{\circ} \mathrm{C}$ for $7 \mathrm{~min}$. Annealing temperatures were individualised for each primer pair for the nine exons of MEN1, six exons of CASR, 17 exons of HRPT2 and 542 base pair putative $M E N I$ promoter and are available on request. PCR products were visualised by ethidium bromide staining on $2 \%$ agarose gel then purified using an UltraClean PCR Clean-up DNA Purification Kit (Mo Bio Laboratories) according to the manufacturer's instructions.

Sequencing reactions employed the same primer pairs used for PCR. Reactions were carried out in $10 \mu \mathrm{l}$ volumes containing $5 \mu \mathrm{l}$ purified PCR product, $4 \mu \mathrm{l}$ Big Dye Terminator Version 2 (ABI Prism) and 1.6 pmol primer. Thermal cycling involved 25 (MEN1) or 30 (HRPT2, CASR) cycles of $94^{\circ} \mathrm{C}$ for $15 \mathrm{~s}, 50$ or $55^{\circ} \mathrm{C}$ for $10 \mathrm{~s}$, and $60^{\circ} \mathrm{C}$ for $4 \mathrm{~min}$.

\begin{tabular}{|c|c|c|c|c|c|c|}
\hline ID & $\begin{array}{l}\text { Age }(y) \text { at } \\
\text { diagnosis }\end{array}$ & $\begin{array}{l}\text { Sex } \\
M / F\end{array}$ & $\begin{array}{l}\text { Initial } \\
\text { presentation }\end{array}$ & $\begin{array}{l}\text { Affected } \\
\text { family }(n)\end{array}$ & Parathyroid histology & MEN1 sequence variation and predicted protein \\
\hline A & 57 & $M$ & Renal calculi & 2 & Four gland hyperplasia & $\begin{array}{l}\text { 255-256insCAGTGGCCGACCTGTCTAT, } 121 \text { amino } \\
\text { acid truncated protein }\end{array}$ \\
\hline B & 54 & M & Renal calculi & 1 & Three gland hyperplasia & $590 \mathrm{C}>\mathrm{T}$ T197I \\
\hline C & 23 & $\mathrm{~F}$ & Asymptomatic & 2 & Hyperplasia & 1057-1059delACT, 407 amino acid truncated protein \\
\hline $\mathrm{D}$ & 56 & $\mathrm{~F}$ & Asymptomatic & 1 & Hyperplasia & $1252 \mathrm{G}>\mathrm{C} \mathrm{D} 418 \mathrm{H}$ \\
\hline $\mathrm{E}$ & 16 & M & Unknown & 1 & Four gland hyperplasia & 1546-1547insC, 529 amino acid truncated protein \\
\hline
\end{tabular}

Nucleotide and amino acid positions start from the initiation codon of MEN1. 
The DNA product was then precipitated in $70 \%$ isopropanol and allowed to dry before being analysed by gel separation on an ABI377 automated sequencer at the Australian Genome Research Facility, Brisbane Division.

All sequence variations detected were confirmed by repeat PCR and sequencing of leukocyte DNA.

Changes in DNA and protein sequences are described according to HUGO nomenclature guidelines. ${ }^{29}$

\section{Statistics}

As biochemical testing was performed in several laboratories, each with different reference ranges, serum calcium (adjusted for albumin) and PTH measurements were all scaled to the same normal distribution by calculating each value's distance in standard deviations from the individual laboratory mean and mapping them to the equivalent point in the reference range $2.15-2.6 \mathrm{mmol} / \mathrm{l}$ for calcium and $1.3-$ $7.6 \mathrm{pmol} / \mathrm{l}$ for PTH.

Means of serum calcium and PTH measurements were compared between subjects with CASR sequence variations and those without using unpaired, two-tailed Student's $t$ tests.

\section{RESULTS}

Of 22 patients with a clinical diagnosis of FIHP, five had heterozygous MENI sequence variations and four heterozygous
CASR sequence variations. The remaining 13 patients had wildtype MEN1, CASR, and HRPT2. Clinical data and sequence variation details for MENI are outlined in table 1. Clinical and laboratory data for the other subjects are provided in table 2 .

\section{CASR}

All four CASR sequence variations detected in these patients were novel and none associated with typical FHH phenotypes in the probands.

Three of the sequence variations were single nucleotide substitutions, 299C $>$ T, 1949T $>C$ and 2065G $>$ A, which predict amino acid changes T100I (extra-cellular domain), L650P (transmembrane region 2), and V689M (transmembrane region 3), respectively, in the calcium-sensing receptor. The fourth was an in-frame single codon deletion 10061008delAAG predicting loss of K336 from the extracellular domain.

Cosegregation with the affected phenotype was sought for each sequence variation. In the T100I kindred (I) three affected and two unaffected, in the V689M kindred $(G)$ four affected and three unaffected, in the K336del kindred $(\mathrm{H})$ two affected and one unaffected members were tested but in the remaining kindred $(\mathrm{F})$, only two affected members were available for genetic testing. Only individuals with a history of hypercalcaemia were shown to have genetic sequence

Table 2 Clinical and laboratory data for FIHP patients with wildtype MEN1 and HRPT2 genotypes

\begin{tabular}{|c|c|c|c|c|c|c|c|c|c|}
\hline \multicolumn{10}{|c|}{ 2a: Subjects with CASR sequence variations } \\
\hline \multirow[b]{2}{*}{ ID } & \multirow{2}{*}{$\begin{array}{l}\text { Age (years) } \\
\text { at } \mathrm{Dx} / \mathrm{Sex} \\
\text { (M/F) }\end{array}$} & \multirow{2}{*}{$\begin{array}{l}\text { Clinical } \\
\text { present-ation }\end{array}$} & \multicolumn{2}{|c|}{$\begin{array}{l}\text { Se } \mathrm{Ca}^{2+} \text { *NR: } 2.15- \\
2.6 \mathrm{mmol} / \mathrm{I}\end{array}$} & \multirow{2}{*}{$\begin{array}{l}\text { Pre-op PTH } \\
\text { NR: } 1.3-7.6 \\
\text { pmol/I }\end{array}$} & \multirow{2}{*}{$\begin{array}{l}\text { Fasting }^{* *} U \\
\mathrm{Ca} / \mathrm{Cr} \text { NR: } \\
0.06-0.6\end{array}$} & \multirow{2}{*}{$\begin{array}{l}24 \mathrm{~h} \mathrm{U} \\
\text { calcium NR: } \\
1-7.5 \mathrm{mmol}\end{array}$} & \multirow{2}{*}{$\begin{array}{l}\text { Number of } \\
\text { affected } \\
\text { family/age at } \\
\text { Dx (year) }\end{array}$} & \multirow{2}{*}{$\begin{array}{l}\text { PT histology (gland number), total } \\
\text { mass (mg) and CASR sequence } \\
\text { variation with predicted amino } \\
\text { acid change }\end{array}$} \\
\hline & & & Pre-op & Post-op & & & & & \\
\hline $\mathrm{F}$ & $58 / F \ddagger$ & Asympt & 2.71 & 2.13 (4 years) & 9.6 & 0.19 & & $1 / 30(\mathrm{RC})$ & $\begin{array}{l}\text { ? Mild hyperplasia (4) } 362 \mathrm{mg} \\
\text { 1949T>C predicting L650P }\end{array}$ \\
\hline$G$ & $64 / F \S$ & Asympt OP & 2.77 & 2.54 (4 years) & 13.3 & 0.5 & & $3 / 63,51,46$ & $\begin{array}{l}\text { Hyperplastic nodules (3) } 390 \mathrm{mg} \\
2065 \mathrm{G}>\mathrm{A} \text { predicting V689M }\end{array}$ \\
\hline $\mathrm{H}$ & $53 / \mathrm{F}$ & RC & 2.90 & & 5.7 & & 8.5 & $2 / 87,29(\mathrm{RC})$ & $\begin{array}{l}\text { Surgery pending } 1006- \\
\text { 1008delAAG predicting K336del }\end{array}$ \\
\hline । & $45 / \mathrm{M}+$ & Panc & 3.1 & 2.86 (8 months) & 6.5 & 0.29 & & $2 / 72,11$ & $\begin{array}{l}\text { PT admixed with adipose tissue (4) } \\
900 \mathrm{mg} 299 \mathrm{C}>\mathrm{T} \text { predicting T100। }\end{array}$ \\
\hline
\end{tabular}

2b: Subjects with wildtype CASR

\begin{tabular}{|c|c|c|c|c|c|c|c|c|c|}
\hline \multirow[b]{2}{*}{ ID } & \multirow{2}{*}{$\begin{array}{l}\text { Age (years) } \\
\text { at } D x / \text { sex } \\
(M / F)\end{array}$} & \multirow{2}{*}{$\begin{array}{l}\text { Clinical } \\
\text { present-ation }\end{array}$} & \multicolumn{2}{|c|}{$\begin{array}{l}\mathrm{Se} \mathrm{Ca}^{2+*} \mathrm{NR}: \\
2.15-2.6 \mathrm{mmol} / \mathrm{l}\end{array}$} & \multirow{2}{*}{$\begin{array}{l}\text { Pre-op PTH } \\
\text { NR: } 1.3-7.6 \\
\text { pmol// }\end{array}$} & \multirow{2}{*}{$\begin{array}{l}\text { Fasting }^{* *} \mathrm{U} \\
\mathrm{Ca} / \mathrm{Cr} \mathrm{NR}: \\
0.06-0.6\end{array}$} & \multirow{2}{*}{$\begin{array}{l}24 \text { h U } \\
\text { calcium NR: } \\
1-7.5 \mathrm{mmol}\end{array}$} & \multirow{2}{*}{$\begin{array}{l}\text { Number of affected } \\
\text { family/ages at } \\
\text { diagnosis (years) }\end{array}$} & \multirow{2}{*}{$\begin{array}{l}\text { PT histology (gland number) } \\
\text { and total mass (mg) }\end{array}$} \\
\hline & & & Pre-op & Post-op & & & & & \\
\hline J & $49 / \mathrm{F}$ & Asympt & 2.88 & 2.34 & 12.7 & & 13.2 & $1 />50$ & Adenomata (2) $1050 \mathrm{mg}$ \\
\hline K & $23 / M$ & Asympt & 3.1 & 2.45 & 15.0 & 0.38 & & $2 / 54,43$ & Adenoma (1) $6000 \mathrm{mg}$ \\
\hline L & $57 / M$ & $\mathrm{RC}$ & 2.53 & 2.21 & 9.5 & & 17 & $2 / 64,35$ & Hyperplasia (4) $390 \mathrm{mg}$ \\
\hline M & $61 / F$ & $\mathrm{RC}$ & 2.61 & 2.35 & 11 & 0.74 & & $1 / 38$ & Hyperplasia (4) $795 \mathrm{mg}$ \\
\hline$N$ & $46 / F$ & Asympt & 2.62 & 2.43 & 12.9 & & 5.8 & $1 / 30$ & Adenoma (1) $320 \mathrm{mg}$ \\
\hline O & $45 / F$ & Asympt & 2.7 & N/A & 28.0 & & 8 & $2 / 63,48$ & Surgery declined \\
\hline$P$ & $40 / \mathrm{F}$ & HT & 2.73 & 2.35 & 13.9 & $\mathrm{~N} / \mathrm{A}$ & N/A & $2 / 80,62$ & Adenoma (1) $2443 \mathrm{mg}$ \\
\hline$Q$ & $38 / \mathrm{F}$ & $\mathrm{HT}$ & 2.63 & 2.42 & 12.0 & & 12.3 & $1 / 53$ & Adenoma (1) $494 \mathrm{mg}$ \\
\hline$R$ & $20 / M$ & Polydip & 3.1 & 2.15 & 50.6 & & 31.9 & $1 / 30$ & Adenoma (1) N/A \\
\hline S & $57 / F$ & Asympt & $1.44^{\top}$ & 2.56 & N/A & $\mathrm{N} / \mathrm{A}$ & N/A & 4/30, unknown & N/A $(4+)$ N/A \\
\hline $\mathrm{T}$ & $45 / \mathrm{F \dagger}$ & Asympt & 2.9 & 3.05 & 9.9 & & 5 & $4 / 58,36,32,32$ & Adenoma (1) N/A \\
\hline U & $71 / F$ & Asympt & 2.77 & 2.5 & 15.1 & 0.19 & & $1 / 90$ & Benign PT (1) 205 mg \\
\hline V & $39 / M$ & $\mathrm{RC}$ & 2.95 & 1.96 & 13.2 & & 17.7 & $1 / 27$ & Hyperplasia (5) 1209 mg \\
\hline
\end{tabular}

*corrected for serum albumin

**early morning spot

thypercalcaemia persisted after surgery or recurred within 12 months of surgery

łoffspring with hypercalcaemia, hypercalciuria and nephrolithiasis

§osteoporotic at presentation.

Tionised calcium, the only level available for this subject (NR: $<1.29)$

N/A: not available

Dx, diagnosis; Se, serum; U, urinary; PT, parathyroid; asympt, asymptomatic; OP, osteoporosis; RC, renal calculus; HT, hypertension; polydip, polydipsia; panc, pancreatitis; Nucleotide and amino acid positions start from the initiation codon of CASR. 
variations. Normocalcaemic family members had wildtype CASR. No one with a CASR sequence variation had sequence variations in MEN1 or HRPT2.

The common, benign CASR polymorphisms ${ }^{19}$ were also found, as expected, among the 22 subjects. These included A986S $(n=4)$, R990G $(n=2)$, and Q1011E $(n=1)$. These were heterozygous except for one homozygous subject who presented with pancreatitis and hypercalcaemia and was found to also have the T100I CASR sequence variation.

Both the proband with urinary $\mathrm{Ca} / \mathrm{Cr}$ of 0.19 (F) and her hypercalciuric offspring were normocalcaemic 4 years and 22 months, respectively, after subtotal parathyroidectomy. The subject with osteoporosis $(G)$ remained normocalcaemic for 4 years post operatively. However, characteristic of subjects with inactivating CASR mutations, the other proband who had surgery (I) had persistent hypercalcaemia postoperatively.

The total mass of parathyroid tissue removed at surgery (362-900 mg) exceeded the upper limit of normal total gland mass $(208 \mathrm{mg})^{30}$ in all three cases. Similar total gland weights have been reported, combined with hyperplasia histologically. ${ }^{14}{ }^{15}$ However, in these three only one subject had clear evidence of parathyroid hyperplasia (G), consistent with an older report of 12 unrelated subjects in which increased gland size and cellularity were found to be unusual. ${ }^{22}$

Mean preoperative serum calcium, corrected for albumin, expressed as a proportion of the upper limit of the laboratory normal range, was not significantly different between the group with CASR sequence variations (2.87 \pm 0.09$)$ (mean \pm SEM) and the group with no sequence variation $(2.79 \pm 0.06)(p=0.49)$. The CASR sequence variation group had a lower mean serum PTH concentration $(8.8+1.7)$ than the other group $(17.0+3.4)$, but this was not statistically significant $(\mathrm{p}=0.19)$.

\section{Others}

The 13 individuals with wildtype gene sequences had more heterogeneous parathyroid histopathology. There were six single adenomas, one case of two adenomata and four cases of multiglandular disease. One subject has declined parathyroid surgery but has a family history of adenoma. Persistent hypercalcaemia following surgery occurred in one of these subjects.

\section{DISCUSSION}

Characteristic of primary hyperparathyroidism in developed countries, the majority $(n=13)$ of these subjects were asymptomatic at the time of diagnosis, with hypercalcaemia an incidental finding on biochemical serum screening or on investigation of a kindred with hypercalcaemia. Six others presented with nephrolithiasis, the commonest presenting symptom for primary hyperparathyroidism in general. ${ }^{31}$ Two subjects had hypercalcaemia revealed on investigation of hypertension. The association of hypertension with primary hyperparathyroidism is well known although a causal link has not been established. ${ }^{32}$

\section{MEN 1}

Of the five MEN1 sequence variations, one (1546-1547insC, kindred E) has been previously reported. ${ }^{33}$ Of the remaining two frameshift mutations, only 1057-1059delACT (C) has been shown to cosegregate with the disease in three affected and two unaffected family members. The other (A) has not yet been investigated due to inability or reluctance of family members to be tested, however, the predicted truncation of the MENI encoded protein menin makes disease causation by both frameshift sequence variations likely. Cosegregation of the two missense sequence variations has also not been tested, but D418H (D) resembles the known D418N muta- tion $^{33}$ and if either, or both, represent benign variants, they are very uncommon, having not been previously reported nor detected in over 300 reference individuals in this laboratory.

Subjects with MENI sequence variations all had multigland hyperplasia at surgery. This observation and the finding of five patients with MENI sequence variations in this cohort confirm previous reports that a minority of cases of FIHP are due to incomplete expressions of mutant MENI genotypes. $^{3}{ }^{13} 34$

MEN1 genotyping, therefore, appears worthwhile in FIHP families, especially when multigland parathyroid hyperplasia is found at surgery. The detection of a MENI mutation allows family screening and is an alert to the likelihood of other endocrinopathies occurring in the kindred which can then be monitored.

\section{CASR}

Although in vitro functional characterisation of these four sequence variations is required to confirm causative roles in these phenotypes, the cosegregation of sequence variation with affected phenotype provides strong support for this role. While they may represent benign variants, none have been observed in the past in several studies involving hundreds of unaffected subjects of various ethnicities. ${ }^{19}$

Detection of inactivating CASR mutations in kindreds with provisional diagnoses of FIHP has been previously reported. ${ }^{14}{ }^{15}$ In this study three of the probands with CASR sequence variations had fasting (early morning spot) urine $\mathrm{Ca} / \mathrm{Cr}$ within the normal range, as did others for whom the provisional diagnosis of FIHP still applies. These 'normal' fasting urine $\mathrm{Ca} / \mathrm{Cr}$ results did not exclude $\mathrm{FHH}$, but pancreatitis in one proband (I), offspring with hypercalcaemia, hypercalciuria, and nephrolithiasis in another (F), and osteoporosis (T scores: L2-4: -3.6 , neck of femur: -2.8 ) with "hyperplastic nodules" in three parathyroids of the third (G) favoured the provisional diagnoses of FIHP.

The individual with elevated $24 \mathrm{~h}$ urine calcium, nephrolithiasis, nephrocalcinosis and a CASR sequence variation has clinically similar offspring $(\mathrm{H})$. A large kindred with hypercalcaemia, hypercalciuria, and renal calculi has recently been described with an inactivating missense mutation in the cytoplasmic tail of CASR. ${ }^{14}{ }^{15}$

These four subjects with CASR sequence variations all presented with hypercalcaemia and unsuppressed parathyroid hormone with apparent complications in themselves and/ or affected relatives. The $24 \mathrm{~h}$ urine calcium and fasting (early morning spot) urine $\mathrm{Ca} / \mathrm{Cr}$ measurements did not discriminate between these patients and those with FIHP because patients with mild primary hyperparathyroidism of any aetiology may have urine calcium excretion within the normal range and because one CASR sequence variation positive subject had hypercalciuria. Spot urine $\mathrm{Ca} / \mathrm{Cr}$ has been shown to correlate well with $24 \mathrm{~h}$ urine calcium excretion ${ }^{35} 36$ and is much less error prone to collect (therefore more likely to be accurate) in the clinical setting than a $24 \mathrm{~h}$ specimen. The $24 \mathrm{~h}$ calcium/creatinine clearance ratio, not measured in these clinical settings, has been well characterised in typical FHH, but has also been shown to lack the power to discriminate between FHH and mild primary hyperparathyroidism. ${ }^{1}$

It is generally accepted that about $95 \%{ }^{21}$ of patients with FHH who undergo subtotal parathyroidectomy will remain hypercalcaemic. However, absence of surgical cure was also a poor discriminator between FIHP and CASR mediated hypercalcaemia in this small group and may indicate that normocalcaemia following surgery is more common than currently understood.

Kindreds with inactivating CASR mutations and affected members without typical FHH phenotypes are not a new 
phenomenon, but these results highlight a need to revise the assessment of individuals with apparent FIHP with multigland involvement, in the individual or relative, to include direct CASR mutation testing where possible.

There may be many families with unidentified inactivating CASR mutations and atypical or variable phenotypes being managed as FIHP. The benefit of identifying these families is that if parathyroidectomy is required, for example for nephrolithiasis, a radical surgical approach can be taken. ${ }^{15}$ If the kindred contains members with hypocalciuria and no other complication, they can be treated conservatively, rather than possibly undergoing unnecessary surgery, influenced by the clinical course of a family member. Based on available figures, about $2 / 3^{10}{ }^{11}$ of these families should be identifiable by direct CASR mutation testing. Identifying these families will also add to current knowledge of the phenotypes associated with inactivating CASR mutations and their relative frequencies.

The availability and cost of genetic testing are limiting factors in this approach but both should improve in the long term. A genetic test is less costly than parathyroidectomy and may be of benefit to many members of a kindred. In addition, it may be the only way of confirming a diagnosis in a small or scattered kindred or one with some members unwilling to be investigated.

\section{HRPT2}

Although there were no HRPT2 sequence variations found in this study, this was surprising in the case of kindred R. This is a small kindred with only two affected members, one having succumbed to parathyroid carcinoma and found to have polycystic disease of the kidneys on post-mortem examination, the other having had a large parathyroid adenoma excised at the age of 20 years and being free of renal and gnathic anomalies. It is possible that this family has a large deletion in HRPT2 not detectable by the direct DNA sequencing method used in this study.

HRPT2 sequencing will be invaluable for the management of families with inherited hyperparathyroidism and fibroosseous jaw tumours. More than half of these kindreds are likely to have a sequence variation detected in the coding region of HRPT2. ${ }^{6}$

However, despite the report of one family with FIHP with an HRPT2 mutation ${ }^{6}$ and the variable expressivity of HRPT2 mutations, making jaw tumours likely in only $40 \%$ and renal lesions in only $23 \%,{ }^{6}$ the findings of this study indicate that HRPT2 mutation testing should not be routine in families with FIHP as it is an expensive and time consuming process to sequence the 17 exons and is unlikely to yield a useful result for the patient and family.

\section{Others}

RET testing for MEN2A was not considered necessary in this cohort as virtually all affected members of MEN2A kindreds develop medullary thyroid carcinoma (MTC), indicated by elevated plasma calcitonin, ${ }^{37}{ }^{38}$ with or without a palpable thyroid mass. Up to $50 \%$ of people with MEN2A may eventually develop primary hyperparathyroidism ${ }^{3}$, but the average age at diagnosis of MTC in MEN2A is younger (29 years) than that for hyperparathyroidism (36 years), ${ }^{37}$ and hyperparathyroidism is rarely the initial presentation of MEN2A. ${ }^{3}$ In the subgroup with wildtype MENI and CASR, all but two ( $\mathrm{Q}$ and $\mathrm{V}$ ) families have affected members now greater than 60 years of age without evidence of MTC. While it is possible that a family with occult MEN2A has been misdiagnosed, the unlikelihood of this argues against undertaking RET testing of these subjects.

The genetic basis for most cases of FIHP has yet to be established. Given the histopathological heterogeneity of the disorder, that a subset of patients with this phenotype has been shown to have MEN1, CASR, or HRPT2 mutant genotypes, and that not all genetic mutations causing MEN1 or HPT-JT have been identified, it seems probable that more than one causative genotype has yet to be described in relation to FIHP.

Some genetic regions of interest to target in this pursuit have been defined through loss of heterozygosity stu$\operatorname{dies}^{17} 3940$ and comparative genomic hybridization ${ }^{41}$ of parathyroid tissue as well as the genetic linkage studies which identified the MEN1 and HRPT2 chromosomal regions. In MEN1 and HRPT2 genetic linkage studies, linkage has been made to the chromosome regions where MENI or HRPT2 are located without mutations in these genes being found by direct sequencing in all affected subjects. ${ }^{46}$ While this may indicate the presence of other associated genes in these regions, large deletions of DNA or mutations in non-protein coding regions of the known genes, undetected by currently used sequencing methods, may be responsible for these phenotypes. $^{42-44}$

Therefore, areas which warrant further scrutiny include the genes surrounding MEN1 and HRPT2 loci, the nonprotein coding regions of MEN1 and HRPT2 as well as the reported loci on chromosomes 1p, 6q, 9p 11p, 13q, 15q, 16p, and $19 \mathrm{p} .{ }^{17}{ }^{39}{ }^{40}$ Definitive analysis would require a genomewide scan of a large number of well defined FIHP kindreds without MENI or CASR mutations.

The diagnosis and management of FIHP and other familial primary hyperparathyroidism continues to rely on clinical, laboratory, and histological findings with careful examination of the family. The addition of MENI and CASR mutation testing in families with multiglandular involvement is likely to identify kindreds with occult MENI and atypical presentations of mutant CASR genotypes with resultant management benefits to these families. With the current mutation testing techniques, however, a negative genetic test cannot fully exclude a diagnosis.

\section{ACKNOWLEDGEMENTS}

We wish to thank Dr M Drinkwater for assistance with the statistical analysis. JW is a recipient of a National Health and Medical Research Council Medical Postgraduate Scholarship. JBP is a Wellcome Senior Research Fellow in Medical Science.

\section{Authors' affiliations}

J Warner, A Sweet, E Mackenzie, J B Prins, J Cardinal, Department of Diabetes and Endocrinology, Princess Alexandra Hospital, Ipswich Rd, Woolloongabba 4102, Qld, Australia

J Warner, A Sweet, J B Prins, D Singh, D Perry-Keene, University of Queensland, 4072, Qld, Australia

M Epstein, John Hunter Hospital, Newcastle, 2300, NSW, Australia

J Burgess, Department of Medicine, University of Tasmania, Hobart, Tas., Australia

S Stranks, Ashford Medical Center, Ashford, SA, Australia

P Hill, Wickham Tce, Brisbane, Qld, Australia

D Perry-Keene, Department of Endocrinology, Royal Brisbane Hospital, Qld, Australia

D Learoyd, B Robinson, Department of Endocrinology and Cancer Genetics, Kolling Institute, Royal North Shore Hospital and University of Sydney, NSW, Australia

P Birdsey, Midhurst Ave, Christie Downs, 5164, SA, Australia

B T Teh, Laboratory of Cancer Genetics, Van Andel Research Institute, Grand Rapids, MI, USA

\section{REFERENCES}

1 Bilezikian J, Potts JJ, El-Haii Fuleihan G, Kleerekoper M, Neer R, Peacock M, Rastad J, Silverberg S, Udelsman R, Wells S. Summary statement from a workshop on asymptomatic primary hyperparathyroidism: a perspective for the 21 st century. J Clin Endocrinol Metab 2002;87(12):5353-61.

2 Villablanca A, Hoog A, Larsson C. Molecular genetics of familial hyperparathyroidism. J Endocrinol Genet 2001;2:3-12. 
3 Marx S, Simonds W, Agarwal S, Burns A, Weinstein L, Cochran C, Skarulis M, Spiegel A, Libutti S, Alexander H, Chen C, Chang R, Chandrasekharappa SC, Collins F. Hyperparathyroidism in hereditary syndromes: special expressions and special managements. J Bone Miner Res 2002;17(suppl 2):N37-43.

4 Chandrasekharappa SC, Guru SC, Manickham P, Olufemi S-E, Collins F, Emmert-Buck M, Debelenko L, Zhuang Z, Lubensky I, Liotta L, Crabtree J, Wang Y, Roe B, Weiseman J, Boguski M, Agarwal S, Kester M, Kim Y, Heppner C, Dong Q, Spiegel A, Burns A, Marx S. Positional cloning of the gene for multiple endocrine neoplasia-type 1. Science 1997:276(531 1):404-7.

5 Mulligan L, Eng C, Attie M, Lyonnet S, Marsh D, Hyland V, Robinson B, Frilling A, Verellen-Dumoulin C, Safar A. Diverse phenotypes associated with exon 10 mutations of the RET proto-oncogene. Hum Mol Genet 1994;3(12):2163-67.

6 Carpten J, Robbins C, Villablanca A, Forsberg L, Presciuttini S, BaileyWilson J, Simonds W, Gillanders E, Kennedy A, Chen J, Agarwal S, Sood R, Jones M, Moses T, Haven C, Petillo D, Leotlela P, Harding B, Cameron D, Pannett A, Hoog A III HH, James-Newton L, Robinson B, Zarbo R, Cavaco B, Wassif W, Perrier N, Rosen I, Kristoffersson U, Turnpenny P, Farnebo L-O, Besser G, Jackson C, Morreau H, Trent J, Thakker R, Marx S, Teh B, Larsson C, Hobbs M. HRPT2, encoding parafibromin, is mutated in hyperparathyroidismaw tumour syndrome. Nat Genet 2002;32:676-80.

7 Pollak M, Brown E, Chou Y, Hebert S, Marx S, Steinmann B, Levi T, Seidman C. Mutations in the human calcium-sensing receptor gene cause familial hypocalciuric hypercalcaemia and neonatal severe hyperparathyroidism. Cell 1993;75:1297-1303.

8 Giraud S, Zhang C, Sinilnikova O, Wautot V, Salandre J, Buisson N, Waterlot C, Bauters C, Porchet N, Aubert J, Emy P, Delemer B, Chabre O, Niccoli P, Leprat F, Emperauger B, Cougard P, Goudet P, Sarfati E, Riou $J_{\text {, }}$ Guichard S, Rodier M, Calender A, et al. Germ-line mutation analysis in patients with multiple endocrine neoplasia type 1 and related disorders. Am J Hum Genet 1998:63(2): 455-67.

9 Eng C, Clayton D, Schuffenecker I, Lenoir G, Cote G, Gagel R, Van Amstel H, Lips C, Nishisho I, Takai S-I, Marsh D, Robinson B, Frank-Rave K, Friedhelm R, Xue F, Noll W, Romei C, Fink M, Niederle B, Zedenius J, Nordenskiold M, Komminoth P, Hendy G, Gharib H, Thibodeau S, Ponder B, Mulligan L. The relationship between specific RET proto-oncogene mutations and disease phenotype in multiple endocrine neoplasia type 2: International RET Mutation Consortium Analysis. JAMA 1996;276(19):1575-79.

10 Chou Y, Pollak M, Brandi M, Toss G, Arnqvist H, Atkinson A, Papapoulos S, Marx S, Brown E, Seidman C. Mutations in the human $\mathrm{Ca}(2+)$-sensingreceptor gene that cause familial hypocalciuric hypercalcaemia. Am J Hum Genet 1995;56:1075-9.

11 Heath HI, Odelberg S, Jackson C, Teh B, Hayward N, Larsson C, Buist N, Krapcho K, Hung B, Capuano I, Garrett J, Leppert M. Clustered inactivating mutations and benign polymorphisms of the calcium receptor gene in familial benign hypocalciuric hypercalcaemia suggest receptor functional domains. $J$ Clin Endocrinol Metab 1996;81:1312-7.

12 Villablanca A, Wassif W, Smith T, Hoog A, Vierimaa O, Kassem M, Dwight T, Forsberg L, Du Q, Learoyd D, Jones K, Stranks S, Juhlin C, Teh B, Carling T, Robinson B, Larsson C. Involvement of the MEN1 gene locus in familial isolated hyperparathyroidism. Eur J Endocrinol 2002;147:313-22.

13 Teh BT, Esapa CT, Grandell U, Houlston R, Nordenskiöld M, Larsson C Familial isolated hyperparathyroidism associated with a constitutional MEN1 mutation. Am J Hum Genet 1998:63:1544-49.

14 Simonds W, James-Newton L, Agarwal S, Yang B, Skarulis M, Hendy G, Marx S. Familial isolated hyperparathyroidism: clinical and genetic characteristics of 36 kindreds. Medicine (Baltimore) 2002;81:1-26

15 Carling T, Szabo E, Bai M, Ridefelt P, Gustavsson P, Trivedi S, Hellman P, Brown E, Dahl N, Rastad J. Familial hypercalcemia and hypercalciuria caused by a novel mutation in the cytoplasmic tail of the calcium-sensing receptor. $J$ Clin Endocrinol Metab 2000;85(5):2042-47.

16 Matsuki T, Nishiura H, Jo Y, Kinoshita H, Morioka M, Tanaka H. Familial isolated hyperparathyroidism: a report of two cases. Nippon Hinyokika Gakkai Zasshi 2000;91(1):33-6

17 Yoshimoto K, Endo H, Tsuyuguchi M, Tanaka C, Kimura T, Kato G, Sano T, Itakura $M$. Familial isolated primary hyperparathyroidism with parathyroid carcinomas: clinical and molecular features. Clin Endocrinol (Oxf) 1998;48:67-72.

18 Wassif W, Moniz C, Friedman E, Wong S, Weber G, Nordenskjold M, Peters T, Larsson C. Familial isolated hyperparathyroidism: a distinct genetic entity with an increased risk of parathyroid cancer. J Clin Endocrinol Metab 1993:77: 1485-89.

19 Hendy G, D'Souza-Li, Yang B, Canaff L, Cole D. Mutations of the calciumsensing receptor (CASR) in familial hypocalciuric hypercalcaemia, neonatal severe hyperparathyroidism and autosomal dominant hypocalcaemia. Hum Mutat 2000;16(4):281-96.

20 Hinnie J, Bell E, McKillop E, Gallacher S. The prevalence of familial hypocalciuric hypercalcemia. Calcif Tissue Int 2001;68:216-18

21 Marx S, Attie M, Levine M, Spiegel A, Downs RJ. The hypocalciuric or benign variant of familial hypercalcemia: clinical and biochemical features in fiffeen kindreds. Medicine (Baltimore) 1981;60(6):397-412.
22 Law W, Carney J, Heath HI. Parathyroid glands in familial benign hypercalcemia (familial hypocalciuric hypercalcemia). Am J Med 1984;76:1021-26.

23 Hanibuchi N, Maruyama T, Menju M, Toyoshima H, Yamamoto T, Fukumoto S, Konishi I. Marked hypercalcemia in a patient with hypocalciuric hypercalcemia without a mutation in the calcium-sensing receptor gene. Intern Med 2002;41:1 153-57.

24 Pasieka J, Andersen M, Hanley D. Familal benign hypercalcaemia: hypercalciuria and hypocalciuria in affected members of a small kindred. Clin Endocrinol (Oxf) 1990;33:429-33.

25 Pearce S, Wooding C, Davies M, Tollefsen S, Whyte M, Thakker R. Calciumsensing receptor mutations in familial hypocalciuric hypercalcaemia with recurrent pancreatitis. Clin Endocrinol (Oxf) 1996:45:657-80.

26 Gunn I, Wallace J. Urine calcium and serum ionized calcium, total calcium and parathyroid hormone concentrations in the diagnosis of primary hyperparathyroidism and familial benign hypercalcaemia. Ann Clin Biochem 1991;29:52-8.

27 Miller S, Dykes D, Polesky H. A simple salting out procedure for extracting DNA from human nucleated cells. Nucleic Acids Res 1988;16(3):1215.

28 Karges W, Jostarndt K, Maier S, Flemming A, Weitz M, Wissmann A Feldmann B, Dralle H, Wagner P, Boehm B. Multiple endocrine neoplasia type 1 (MEN1) gene mutations in a subset of patients with sporadic and familial primary hyperparathyroidism target the coding sequence but spare the promoter region. J Endocrinol 2000;166:1-9.

29 den Dunnen J, Antonarakis E. Nomenclature for the description of human sequence variations. Hum Genet 2001;109:121-4.

30 Grimelius L, Akerstrom G, Johansson H, Juhlin C, Rastad J. The parathyroid glands. In: Kovacs K, Asa L, eds. Functional endocrine pathology. Malden, MA: Blackwell Science, 1998:381-441.

31 Silverberg S, Shane E, Jacobs T, Siris E, Gartenberg F, Seldin D, Clemens T, Bilezikian J. Nephrolithiasis and bone involvement in primary hyperparathyroidism. Am J Med 1990:89:327-34.

32 Garcia de la Torre N, Wass J, Turner H. Parathyroid adenomas and cardiovascular risk. Endocrine-Related Cancer 2003;10:309-322.

33 Teh B, Kytölä S, Farnebo F, Bergman L, Wong F, Weber G, Larsson C, Skogseid B, Beckers A, Phelan C, Edwards M, Epstein M, Alford F, Hurley D, Grimmond S, Silins G, Walters M, Stewart C, Cardinal J, Khodaei S, Parente F, Tranebjærg L, Jorde R, Menon J, Khir A, Tan T, Chan S, Zaini A, Khalid B, Sandelin K, Thompson N, Brandi M-L, Warth M, Stock J, Leisti J, Cameron D, Shepherd J, Öberg K, Salmela P. Mutation analysis of the MEN1 gene in multiple endocrine neoplasia type 1, familial acromegaly and familial isolated hyperparathyroidism. J Clin Endocrinol Metab 1998;83:2621-26.

34 Kassem M, Kruse T, Wong F, Larsson C, Teh B. Familial isolated hyperparathyroidism - a variant of MEN1. J Clin Endocrinol Metab 2000;85: 165-167

35 Ogawa Y, Yonou H, Hokama S, Oda M, Morozumi M, Sugaya K. Urinary saturation and risk factors for calcium oxalate stone disease based on spot and 24-hour urine specimens. Front Biosci 2003:8:al67-76.

36 Gokce C, Gokce O, Baydine C, Ithan N, Alasehirli E, Ozkucuk F, Tasci M, Atilkeler M, Celebi $H$, Arslan N. Use of random urine samples to estimate total urinary calcium and phosphate excretion. Arch Intern Med 1991;151(8):1587-1588

37 Howe J, Norton J, Wells S. Prevalence of pheochromocytoma and hyperparathyroidism in multiple endocrine neoplasia type $2 \mathrm{~A}$ : results of longterm follow-up. Surgery 1993;114(6):1070-77.

38 Brandi M, Gagel R, Angeli A, Bilezikian J, Beck-Peccoz P, Bordi C, ConteDevolx B, Falchetti A, Gheri R, Libroia A, Lips C, Lombardi G, Mannelli M, Pacini F, Ponder B, Rave F, Skogseid B, Tamburrano G, Thakker R, Thompson N, Tomassetti P, Tonelli F, Wells S, Marx S. Guidelines for diagnosis and therapy of MEN type 1 and type 2. J Clin Endocrinol Metab $2001 ; 86(12): 5658-71$.

39 Tahara H, Smith A, Gaz R, Cryns V, Arnold A. Genomic localisation of novel candidate tumour suppressor gene loci in human parathyroid adenomas. Cancer Res 1996:56:599-605.

40 Correa P, Juhlin C, Rastad J, Akerstrom G, Westin G, Carling T. Allelic loss in clinically and screening-detected primary hyperparathyroidism. Clin Endocrinol (Oxf) 2002:56:113-7.

41 Palanisamy N, Imanishi Y, Rao P, Tahara H, Chagant R, Arnold A. Novel chromosomal abnormalities identified by comparative genomic hybridization in parathyroid adenomas. J Clin Endocrinol Metab 1998;83:1766-70.

42 Mattick J. Non-coding RNAs: the architects of eukaryotic complexity. EMBO Rep 2001;2(11):986-91.

43 Bagnall R, Waseem N, Green P, Colvin B, Lee C, Giannelli F. Creation of a novel donor splice site in intron 1 of the factor VIII gene leads to activation of a $191 \mathrm{bp}$ cryptic exon in two haemophilia A patients. Br J Haematol 1999; 107:766-71.

44 King K, Flinter F, Nihalani V, Green P. Unusual deep intronic mutations in the COL4A5 gene cause $X$ linked Alport syndrome. Hum Genet 2002;111:548-54. 